\title{
THE RÔLE OF THE PITUITARY IN THE REPRODUCTION OF THE MALE TAMMAR WALLABY, MACROPUS EUGENII
}

\author{
JOHN P. HEARN* \\ Zoology Department, Australian National University, \\ Canberra, Australia
}

(Received 13th September 1974)

The male wallaby reaches sexual maturity at about 18 months of age, and spermatogenesis in the adult persists throughout the year. Mating activity, however, takes place mainly in late January and early February when the females give birth and have a post-partum oestrus. No mating occurs between June and December when the females are in seasonal anoestrus (Berger, 1970).

In the present study, twenty-three adult male wallabies were examined for any evidence of seasonal changes in testis and accessory organ weights and histology, and in plasma gonadotrophin levels. Hypophysectomy and gonadectomy were used to determine the extent to which the reproductive tract is supported by the pituitary. The animals selected were all between 5 and $6.5 \mathrm{~kg}$ body weight, as between these body weights the normal variation in organ weights is small.

The wallabies were caught on Kangaroo Island, South Australia, and were maintained in large enclosures at the C.S.I.R.O. Division of Wildlife Research in Canberra. The techniques used for blood sampling and hypophysectomy and the radioimmunoassay for gonadotrophin have been reported previously (Hearn, 1974, 1975). The reproductive tract of the wallaby is similar to that of the kangaroo (Rodger \& White, 1974). Testicular biopsies were taken from intact and hypophysectomized wallabies under light ether anaesthesia. A 5-mm incision was made through the scrotum and the tunica albuginea, and a small piece of testis was removed. The wound was dusted with sulphanilamide and sutured with a single stitch. The process was usually completed within 3 to $5 \mathrm{~min}$ and the animals showed no signs of stress. Gonadectomy was performed using sheep castration rings. The necrotic scrotum and testes fell off within 10 days and the area was completely healed within 15 days.

Scrotal size (length and breadth) was measured monthly on four adult males kept with females for 1 year, and was measured every 10 days on six hypophysectomized wallabies. Gonadotrophin levels in plasma samples, taken monthly from the four intact wallabies and at autopsy from the hypophysectomized animals, were analysed by radioimmunoassay (Hearn, 1974). All samples were analysed in the same assay to eliminate any between-assay variation. Eleven intact males were killed, five in the breeding season and six in the non-breeding season. Three males were hypophysectomized during the

* Present address: M.R.G. Unit of Reproductive Biology, 39 Chalmers Street, Edinburgh EH3 9ER. 
breeding season and three during the non-breeding season; five were killed 60 days after hypophysectomy and one 120 days after hypophysectomy.

At autopsy, the animals were weighed and lightly anaesthetized. Blood ( 50 to $70 \mathrm{ml}$ ) was taken by heart puncture and the animal was then killed by an intracardiac injection of Nembutal. The testes, epididymides, prostate, Cowper's glands and penis were dissected, blotted and weighed before being fixed for histology. Sperm smears were taken from the fresh cauda epididymidis of all animals at autopsy. Testis measurements were transformed to give the volume of a single testis using the formula for the volume of an oblate spheroid ( $\mathrm{V}=1 / 6 \mathrm{~W}^{2} \mathrm{~L}$, where $\mathrm{V}=$ volume, $\mathrm{W}=$ width of a single testis, $\mathrm{L}=$ length of a single testis).

Table 1. The weights of the reproductive organs of intact adult male wallabies during the breeding and non-breeding seasons, after hypophysectomy and after castration

\begin{tabular}{|c|c|c|c|c|c|}
\hline & \multicolumn{2}{|c|}{ Intact } & \multicolumn{2}{|c|}{ Hypophysectomized } & \multirow{2}{*}{$\begin{array}{l}\text { Castrated } \\
(60 \text { days })\end{array}$} \\
\hline & $\begin{array}{l}\text { season } \\
\text { secus }\end{array}$ & $\begin{array}{l}\text { season } \\
\text { seng }\end{array}$ & 60 days & 120 days & \\
\hline $\begin{array}{l}\text { No. of animals } \\
\text { Testes } \\
\text { Epididymides } \\
\text { Prostate } \\
\text { Cowper's gland } \\
\text { Penis }\end{array}$ & $\begin{array}{c}5 \\
39 \cdot 16 \pm 1 \cdot 30 \\
6 \cdot 76 \pm 0 \cdot 30 \\
41 \cdot 24 \pm 1 \cdot 03 \\
6 \cdot 76 \pm 0 \cdot 26 \\
3 \cdot 63 \pm 0 \cdot 8\end{array}$ & $\begin{array}{c}6 \\
38.53 \pm 0.71 \\
6.50 \pm 0.15 \\
40.52 \pm 1.36 \\
6 \cdot 36 \pm 0.24 \\
3.96 \pm 0.14\end{array}$ & $\begin{array}{c}5 \\
8 \cdot 08 \pm 0 \cdot 50 \\
3 \cdot 10 \pm 0 \cdot 11 \\
10 \cdot 10 \pm 0 \cdot 42 \\
2 \cdot 88 \pm 0 \cdot 21 \\
3 \cdot 51 \pm 0 \cdot 10\end{array}$ & $\begin{array}{c}1 \\
5 \cdot 50 \\
1 \cdot 82 \\
3 \cdot 00 \\
0 \cdot 78 \\
2 \cdot 60\end{array}$ & $\begin{array}{r}\frac{2}{-} \\
10 \cdot \overline{70} \\
3 \cdot 40 \\
3 \cdot 25\end{array}$ \\
\hline
\end{tabular}

Values are expressed as Means \pm S.E.M. in $\mathbf{g}$.

Table 1 shows the weights of the testes and accessory organs of intact, hypophysectomized, and castrated male wallabies. No significant seasonal differences in the weights or in the histology of these organs were found in the intact animals, and the monthly scrotal dimensions remained constant. Spermatozoa taken from the cauda epididymidis of intact wallabies in the breeding and the non-breeding seasons were motile when placed in a drop of saline at $37^{\circ} \mathrm{C}$ on a microscope slide. In all the intact wallabies, a lot of fluid exuded from the reproductive tract when tissues were dissected for histology. The fluid from the testis and epididymis was thin and milky, while that from all parts of the prostate and Cowper's glands was thick, viscous and very glutinous. There was no significant seasonal difference in levels of plasma gonadotrophin, which remained between 3 to $5 \mathrm{ng} / \mathrm{ml}$ throughout the year.

The first effect noticed after hypophysectomy was a rapid shrinkage of the testis and especially of the seminiferous tubules (Text-fig. 1). The testes became soft within 1 week of the operation and the rate of shrinkage was similar in all the animals, irrespective of the time of year that they were hypophysectomized. Plasma levels of gonadotrophin were undetectable after hypophysectomy. A marked decline in the weight of the other organs also occurred (Table 1) and very little fluid exuded from them when they were dissected at autopsy. Smears taken from the cauda epididymidis showed very few $(<10)$ spermatozoa 60 days after hypophysectomy and none at all 120 days after the operation. 
Rapid atrophy of the seminiferous tubules was seen in testicular biopsies taken at the time of hypophysectomy and 5, 15, 30 and 45 days later; by 15 days, there was a complete disorganization of the tubules with masses of

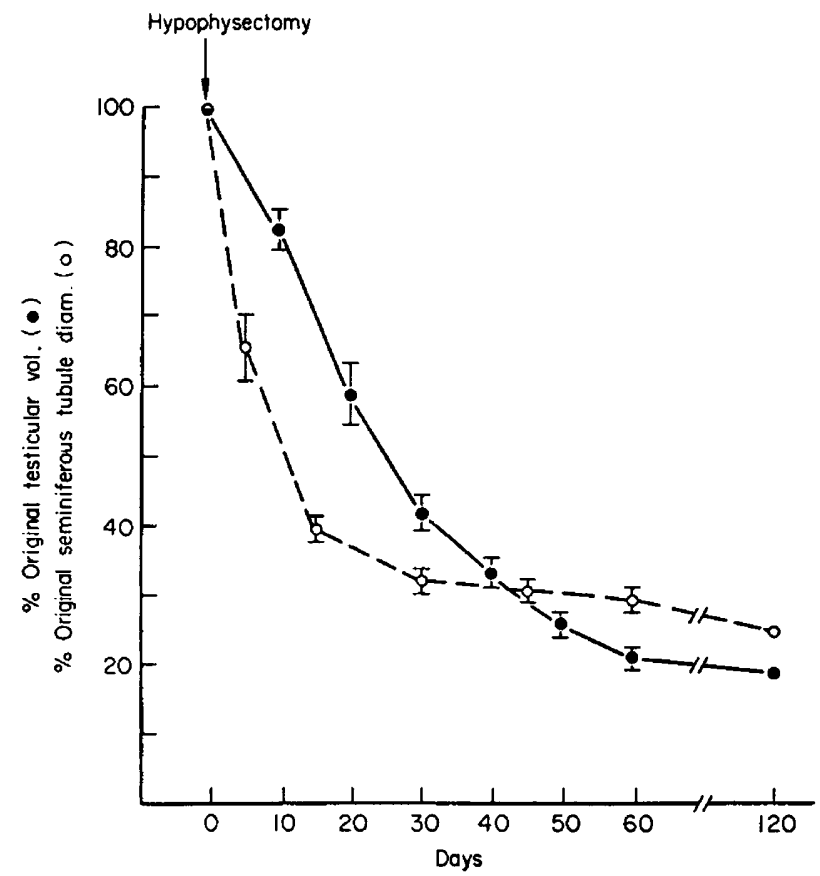

TEXT-FIG. 1. The effects of hypophysectomy on the volume of the testis (O) and on the diameter of the seminiferous tubules (O) of the tammar wallaby. The vertical bars representing the mean \pm S.E.M. are shown for six wallabies, five of which were killed at 60 days after hypophysectomy and one at 120 days after hypophysectomy.

Table 2. The tubule, ductule or alveolar diameters of the reproductive organs of five intact, six hypophysectomized and two castrated wallabies

\begin{tabular}{|c|c|c|c|c|}
\hline & Intact & $\begin{array}{l}\text { Hypophys } \\
60 \text { days }\end{array}$ & $\begin{array}{l}\text { ectomized } \\
120 \text { days }\end{array}$ & $\begin{array}{l}\text { Castrated } \\
(60 \text { days })\end{array}$ \\
\hline $\begin{array}{l}\text { No. of animals } \\
\text { Testis } \\
\text { Caput epididymidis } \\
\text { Cauda epididymidis } \\
\text { Prostate } \\
\text { Cowper's gland }\end{array}$ & $\begin{array}{l}11 \\
430 \pm 22 \\
350 \pm 14 \\
700 \pm 43 \\
249 \pm 8 \cdot 3 \\
422 \pm 22\end{array}$ & $\begin{array}{r}5 \\
120 \pm 6 \cdot 4 \\
120 \pm 4 \cdot 5 \\
141 \pm 9 \cdot 3 \\
93 \pm 4 \cdot 1 \\
129 \pm 9 \cdot 3\end{array}$ & $\begin{array}{r}1 \\
100 \pm 5 \cdot 2 \\
59 \pm 3 \cdot 7 \\
104 \pm 6 \cdot 7 \\
56 \pm 3 \cdot 2 \\
69 \pm 3 \cdot 2\end{array}$ & $\begin{array}{c}\frac{2}{-} \\
- \\
97 \pm 5 \cdot 6 \\
138 \pm 7 \cdot 2\end{array}$ \\
\hline
\end{tabular}

Measurements are given as Mean \pm S.E.M. in $\mu \mathrm{m}$ and for the epididymidis are from counts of entire sections through each region, and for the testis, prostate and Cowper's glands are from counts of five microscope fields at random.

degenerating cells in the lumen. Eventually, only the Sertoli cells and a few peripherally scattered spermatogonia and primary spermatocytes remained. Mitotic figures could be seen in the spermatogonia 60 and 120 days after hypophysectomy, but there was no maturation beyond the primary spermato- 
cyte stage. There was also a marked atrophy in the interstitial cells, with a loss of cytoplasm, and the nuclei became small and densely staining.

After hypophysectomy, there was marked atrophy of the tubule, ductule or alveolar diameters from the testes, cauda and caput epididymidis, prostate and Cowper's glands, especially in the prostate (Table 2). The cuboidal or columnar epithelial linings in the intact animals became pseudostratified squamous or cuboidal after hypophysectomy and all traces of secretory granules were lost from the cytoplasm. The penis showed some loss in weight after hypophysectomy but there were no marked histological changes. The weights and the histology of the remaining organs in wallabies 60 days after castration closely resembled those from animals 60 days after hypophysectomy.

The reproductive system of seasonally breeding males of eutherian species, such as the hedgehog, thirteen-striped ground squirrel, ferret and red deer, declines markedly during the non-breeding season. A similar situation is found in the platypus, Ornithorhynchus anatinus (Temple-Smith, 1973). In the possum, Trichosurus vulpecula, Gilmore (1969) found a fourfold reduction in prostate weight during the non-breeding season. When male squirrels or ferrets were hypophysectomized in the non-breeding season, there were no apparent effects on the reproductive system, but hypophysectomy during the breeding season caused a rapid regression of the reproductive system to the condition seen in the non-breeding season (Rowlands \& Parkes, 1966). Clearly, the effects of hypophysectomy on the reproductive tract are related to the functional state of the testis.

By contrast, the male tammar wallaby showed no marked seasonal changes in the reproductive tract, and there was no significant variation in the plasma gonadotrophin levels. The prostate gland in the wallaby did not show the seasonal changes observed in the possum. The testes regressed at the same rate after hypophysectomy during the breeding and the non-breeding seasons. Thus, although the female is anoestrous between June and December, the pituitary maintains the reproductive tract of the male in breeding condition throughout the year, and there is no marked seasonal cycle in the male wallaby.

I thank Dr C. H. Tyndale-Biscoe for his advice during this study, which was partly supported by a grant to him from the Commonwealth Scientific and Industrial Research Organization.

\section{REFERENCES}

Berger, P. J. (1970) The reproductive biology of the tammar wallaby, Macropus eugenii. Ph.D. thesis Tulane University.

Gilmore, D. P. (1969) Seasonal reproductive periodicity in the male Australian brush tailed possum (Trichosurus vulpecula). F. Zool., Lond. 157, 75-98.

Hearn, J. P. (1974) The pituitary gland and implantation in the tammar wallaby, Macropus eugenii. 7. Reprod. Fert. 39, 235-241.

Hearn, J. P. (1975) Hypophysectomy of the wallaby, Macropus eugenii. Surgical approach and general effects. F. Endocr. 64, (in press).

Rodger, J. G. \& WHITE, I. G. (1974) Carbohydrates of the prostate of two Australian marsupials, Trichosurus vulpecula and Megaleia rufa. 7. Reprod. Fert. 39, 267-273.

Rowlands, I. W. \& Parkes, A. S. (1966) Hypophysectomy and the gonadotrophins. In Marshall's Physiology of Reproduction, 3rd edn, vol. 3, pp. 26-147. Ed. A. S. Parkes. Longmans, London.

Temple-Smith, P. (1973) The reproductive biology of the platypus. Ph.D. thesis, Australian National University. 